\title{
TU/e EmonOWEN

\section{Intramolecularly catalyzed dynamic polyester networks using neighboring carboxylic and sulfonic acid groups}

\section{Citation for published version (APA):}

Zhang, H., Majumdar, S., van Benthem, R. A. T. M., Sijbesma, R. P., \& Heuts, J. P. A. (2020). Intramolecularly catalyzed dynamic polyester networks using neighboring carboxylic and sulfonic acid groups. ACS Macro Letters, 9(2), 272-277. https://doi.org/10.1021/acsmacrolett.9b01023

\section{Document license:}

CC BY-NC-ND

DOI:

10.1021/acsmacrolett.9b01023

Document status and date:

Published: 18/02/2020

\section{Document Version:}

Publisher's PDF, also known as Version of Record (includes final page, issue and volume numbers)

\section{Please check the document version of this publication:}

- A submitted manuscript is the version of the article upon submission and before peer-review. There can be important differences between the submitted version and the official published version of record. People interested in the research are advised to contact the author for the final version of the publication, or visit the $\mathrm{DOI}$ to the publisher's website.

- The final author version and the galley proof are versions of the publication after peer review.

- The final published version features the final layout of the paper including the volume, issue and page numbers.

Link to publication

\section{General rights}

Copyright and moral rights for the publications made accessible in the public portal are retained by the authors and/or other copyright owners and it is a condition of accessing publications that users recognise and abide by the legal requirements associated with these rights.

- Users may download and print one copy of any publication from the public portal for the purpose of private study or research.

- You may not further distribute the material or use it for any profit-making activity or commercial gain

- You may freely distribute the URL identifying the publication in the public portal.

If the publication is distributed under the terms of Article 25fa of the Dutch Copyright Act, indicated by the "Taverne" license above, please follow below link for the End User Agreement:

www.tue.nl/taverne

Take down policy

If you believe that this document breaches copyright please contact us at:

openaccess@tue.nl

providing details and we will investigate your claim. 


\title{
Intramolecularly Catalyzed Dynamic Polyester Networks Using Neighboring Carboxylic and Sulfonic Acid Groups
}

\author{
Huiyi Zhang, Soumabrata Majumdar, Rolf A. T. M. van Benthem, Rint P. Sijbesma,* \\ and Johan P. A. Heuts*
}

Cite This: ACS Macro Lett. 2020, 9, 272-277

Read Online

\section{ACCESS \\ Џll Metrics \& More \\ Article Recommendations \\ Supporting Information}

ABSTRACT: Dynamic covalent bonds in a polymer network lead to plasticity, reshapability, and potential recyclability at elevated temperatures in combination with solvent-resistance and better dimensional stability at lower temperatures. Here we report a simple one-step procedure for the catalyst-free preparation and intramolecularly catalyzed stress-relaxation of dynamic polyester networks. The procedure is based on the coupling of branched $\mathrm{OH}$-end functional polyesters (functionality $\geq 3$ ) by pyromellitic dianhydride (PMDA) or 2,5-bis(methoxy-carbonyl) benzenesulfonic acid resulting in ester linkages with, respectively, a $\mathrm{COOH}$ or a $\mathrm{SO}_{3} \mathrm{H}$ group in a position ortho to the ester bond. This approach leads to an efficient external catalyst-free dynamic polyester

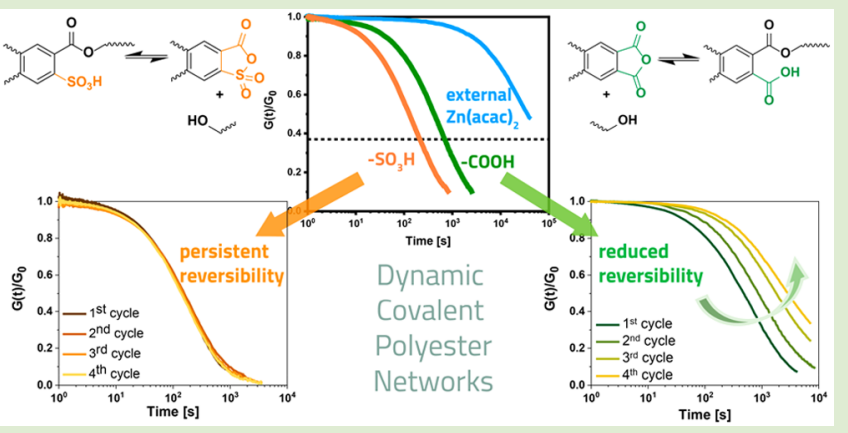
network, in which the topology rearrangements occur via a dissociative mechanism involving anhydrides. The $\mathrm{SO}_{3} \mathrm{H}$-containing network is particularly interesting, as it shows the fastest stress relaxation and does not suffer from unwanted additional transesterification reactions, as was observed in the COOH-containing network.

$\mathrm{D}$ ynamic covalent bonds endow covalently cross-linked networks with plasticity and recyclability at elevated temperatures without compromising their mechanical properties under operating conditions. ${ }^{1-5}$ This advantageous combination of macroscopic properties has resulted in an increasing interest in dynamic covalent networks (DCNs) as promising materials in a range of different applications. ${ }^{6-14}$ Among the ever-growing library of DCNs, dynamic polyester networks, pioneered by Leibler and co-workers, ${ }^{1}$ have received extensive attention because of their potentially broad applicability. ${ }^{15-19}$

Dynamic polyester networks based on transesterification often require additional catalysts, such as $\mathrm{Zn}$ (II) salts, triazacyclodecene, and Brønsted acids. ${ }^{15,16,19,20}$ In such systems, potential catalyst leaching may affect the dynamic properties of the materials and be harmful to the end-users or the environment. ${ }^{21}$ Systems without catalysts or with immobilized catalysts would not suffer these drawbacks, and the aim of the current work is to develop such a system. Catalyst-free dynamic polyester networks have been reported previously but either required a great excess of hydroxyl functionality in the network $^{17,22}$ or in the hyperbranched building blocks, ${ }^{23}$ and relatively restricted efficiencies of the bond exchange were observed. Inspired by mechanisms in enzyme catalysis and neighboring group participation (including in DCNs), ${ }^{11,12}$ we investigated the effect of neighboring carboxylic and sulfonic acid groups on transesterification reactions. A very similar approach (but not involving sulfonic acid groups) was recently reported by $\mathrm{Du}$ Prez and coworkers. ${ }^{24}$ Prompted by this disclosure, we here compare the properties of dynamic polyester networks with neighboring group participation of carboxylic and sulfonic acid groups and demonstrate the sulfonic acid groups to be more effective and less susceptible to potential further cross-linking.

Our approach is a simple one-pot and catalyst-free synthesis involving the coupling of polyester chains with three or more hydroxyl end groups by difunctional chain extenders. Two different $\mathrm{OH}$-endfunctional polyesters were used in this study: a "soft" aliphatic triarm polycaprolactone star polymer (PCL, functionality $=3, M_{\mathrm{n}}=1930 \mathrm{~g} / \mathrm{mol}$, and $T_{\mathrm{g}}=-63{ }^{\circ} \mathrm{C}$ ) and a "hard" amorphous copolymer of neopentyl glycol, hexanediol, terephthalic, and isophthalic acid (PNHTI, average functionality $=3, M_{\mathrm{n}}=4035 \mathrm{~g} / \mathrm{mol}$, and $\left.T_{\mathrm{g}}=40{ }^{\circ} \mathrm{C}\right)$. Networks containing pendent neighboring carboxylic acid groups were prepared from the polyesters by reaction with pyromellitic dianhydride (PMDA, also used by Du Prez and co-workers ${ }^{13}$ ) as the coupling agent (see Figure 1, reaction $\mathrm{A}$ ); gelation occurred within $1 \mathrm{~h}$ of the reaction in toluene at $100{ }^{\circ} \mathrm{C}$ (without the use of any additional catalyst). Networks

Received: December 29, 2019

Accepted: February 4, 2020

Published: February 6, 2020 
(a)

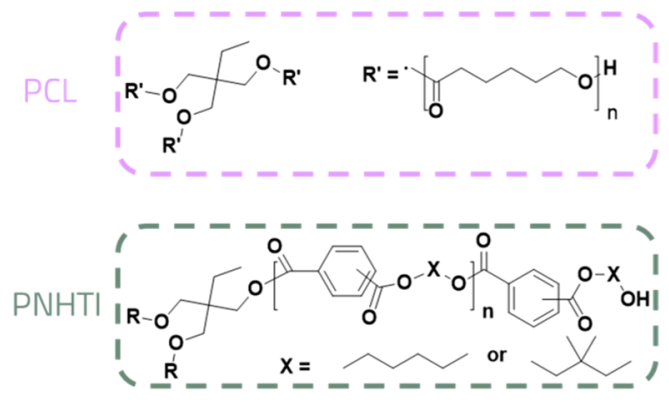

(a)<smiles>O=c1oc(=O)c2cc3c(=O)oc(=O)c3cc12</smiles><smiles>CCOC(=O)c1cc(C(=O)O)c(C(=O)OCC)cc1C(=O)O</smiles>

(b)<smiles>CCOCCOC(=O)c1ccc(C(=O)OCC)cc1S(=O)(=O)O</smiles>

(c) $\mathrm{c}$

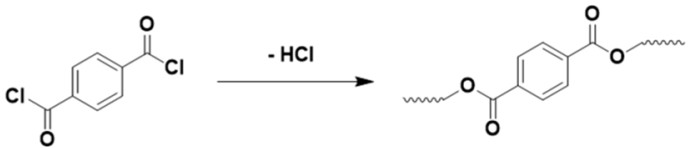

(b)

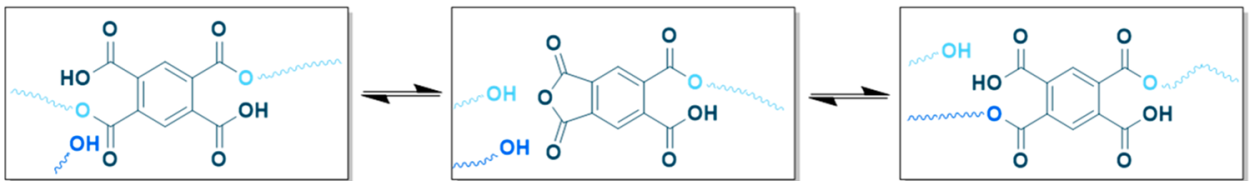

Figure 1. (a) Reactions of network formation with highlighted functional internal acid groups and (b) schematic presentation of the bond rearrangement in networks with neighboring carboxylic acid groups.
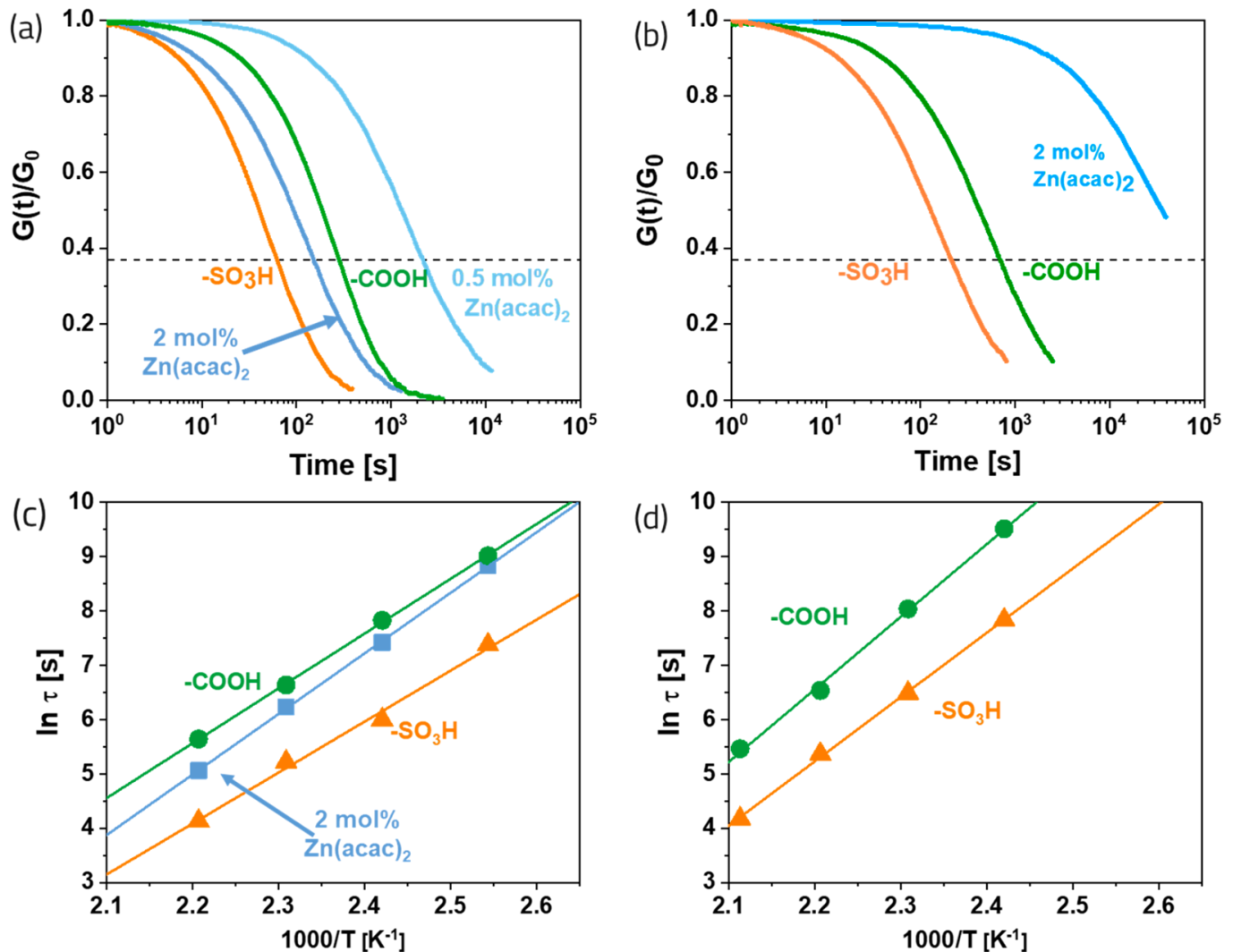

Figure 2. Oscillatory rheology stress relaxation experiments (1\% step strain) on polyester networks with $r=n_{\mathrm{OH}} / n_{\text {linker }}=2.4$ at $180{ }^{\circ} \mathrm{C}$ on $(\mathrm{a}) \mathrm{PCL}-$ and (b) PNHTI-based networks and the corresponding Arrhenius plots of (c) PCL- and (d) PNHTI-based networks. The intersections of the horizontal dotted lines with the stress relaxation curves indicate the points where $G(t) / G_{0}=1 / e$ and $t=\tau^{*}$.

containing neigboring sulfonic acid groups were prepared from the polyesters by a condensation reaction with 2,5-bis(methoxy-carbonyl) benzenesulfonic acid (see Figure 1, reaction $\mathrm{B})$; this transesterification was carried out overnight in toluene at $100{ }^{\circ} \mathrm{C}$ and required effective removal of methanol. After removal of the solvent under reduced pressure, the dry products of reactions $\mathrm{A}$ and $\mathrm{B}$ were compression molded at $160-180{ }^{\circ} \mathrm{C}$ for oscillatory rheology and Dynamic Mechanical Analysis (DMA) measurements. The gel fractions
(>90 wt \%, Table S1) of all samples were estimated by extraction with tetrahydrofuran at room temperature; these high gel fractions confirm the near full completion of the crosslinking reactions. A reference network without any neighboring acid groups was prepared by a reaction of the polyesters with terephthaloyl chloride in toluene at $100{ }^{\circ} \mathrm{C}$ overnight (see Figure 1, reaction C), isolated, and soaked for $24 \mathrm{~h}$ in a chloroform solution containing $\mathrm{Zn}(\mathrm{acac})_{2}$ to obtain samples 
with 2 and $0.5 \mathrm{~mol} \%$ (w.r.t. the ester groups) of a transesterification catalyst in the (dynamic) polyester network.

Stress relaxation experiments revealed the dynamic nature of these polyester networks. The relaxation modulus $G(t)$ was normalized against its value at $t=1 \mathrm{~s}$, which was taken to be the apparent plateau value $\left(G_{0}\right)$ after applying a step strain of $1 \%$ (Figure S2).

Normalized relaxation moduli for both $-\mathrm{COOH}$ - and $-\mathrm{SO}_{3} \mathrm{H}$-containing networks are shown in Figure 2, and it can be seen that full stress relaxation takes place. Although stretched exponentials fit the data better than a single exponential (Maxwell model), the "stretching exponent" is in all cases greater than 0.7 (see SI for more details). Therefore, we still used as the characteristic stress relaxation time $\left(\tau^{*}\right)$ the point in time at which the normalized relaxation modulus $\left(G(t) / G_{0}\right)$ reaches $e^{-1}$ (or $\sim 37 \%$ ). Remarkably, the results shown in Figure $2 \mathrm{a}$ show that, at $180{ }^{\circ} \mathrm{C}$, the PCL-based network with $-\mathrm{SO}_{3} \mathrm{H}$ groups showed a much faster stress relaxation (with $\tau^{*} \approx 60 \mathrm{~s}$ ) than the PCL-based network with $-\mathrm{COOH}$ groups (with $\tau^{*} \approx 300 \mathrm{~s}$ ). Both (external catalystfree) networks also show a significantly faster stress relaxation than the conventional reference system with $0.5 \mathrm{~mol} \%$ of $\mathrm{Zn}(\mathrm{acac})_{2}$ catalyst. Increasing the catalyst content in the reference system from 0.5 to $2 \mathrm{~mol} \%$ results in a value for $\tau^{*}$ that lies between those of the $-\mathrm{COOH}-$ and $-\mathrm{SO}_{3} \mathrm{H}$ containing networks. The observed stress relaxation times of these systems are also significantly faster than those observed in other dynamic polyester networks, ${ }^{16,18,19}$ but significantly slower than those reported for, for example, boroxine ${ }^{25}$ and dioxoborolane ${ }^{26}$ based dynamic networks (see also SI).

Comparing the stress relaxation behavior at $180{ }^{\circ} \mathrm{C}$ of the PCL-based network (Figure 2a) to that of the PNHTI-based network (Figure $2 b$ ), the first thing one notices is that the stress relaxation in the PNHTI-based network is slower for all systems. The $-\mathrm{SO}_{3} \mathrm{H}$-containing network again is characterized by the lowest $\tau^{*}$, now followed by the $-\mathrm{COOH}$ containing network, and this time, the conventional reference system is significantly slower than the other two (even with 2 $\mathrm{mol} \%$ of $\mathrm{Zn}(\mathrm{acac})_{2}$ transesterification catalyst).

All these results show that the ester exchange rate depends on the nature of acid groups, with the $-\mathrm{SO}_{3} \mathrm{H}$-containing networks showing the fastest relaxation, despite its concentration being only half that of the $\mathrm{COOH}$ groups in the $-\mathrm{COOH}$-containing networks with the same amount of linking agent. The temperature dependence of the stress relaxation was investigated in the temperature range of 140$200{ }^{\circ} \mathrm{C}$ (Figure S4), and the resulting relaxation times $\left(\tau^{*}\right)$ are shown in the Arrhenius plots in Figure $2 \mathrm{c}$ and $\mathrm{d}$ for the PCLand PNHTI-based networks, respectively. The resulting Arrhenius parameters are summarized in Table 1.

\section{Table 1. Arrhenius Parameters for Stress Relaxation ${ }^{a}$}

\begin{tabular}{llc}
\multicolumn{1}{c}{ network } & $\tau_{0}\left(10^{-9} \mathrm{~s}\right)$ & $E_{\mathrm{a}}\left(\mathrm{kJ} \cdot \mathrm{mol}^{-1}\right)$ \\
$\mathrm{PCL} / \mathrm{COOH}$ & $62 \pm 20$ & $84 \pm 1$ \\
$\mathrm{PCL} / \mathrm{SO}_{3} \mathrm{H}$ & $68 \pm 54$ & $78 \pm 5$ \\
$\mathrm{PCL} / \mathrm{ref}\left(2 \% \mathrm{Zn}^{2+}\right)$ & $3.4 \pm 0.9$ & $93 \pm 1$ \\
$\mathrm{PNHTI} / \mathrm{COOH}$ & $0.03 \pm 0.04$ & $116 \pm 5$ \\
$\mathrm{PNHTI} / \mathrm{SO}_{3} \mathrm{H}$ & $0.93 \pm 1.54$ & $98 \pm 2$
\end{tabular}

${ }^{a_{T}}$ The characteristic relaxation times were fitted to the following equation: $\tau^{*}=\tau_{0} e^{E_{\mathrm{a}} / R T}$.
In general, the results in Table 1 show lower activation energies for the PCL-based networks and the networks containing the $-\mathrm{SO}_{3} \mathrm{H}$ neighboring acid groups. The former observation suggests an important role of the intrinsic chain dynamics in the stress relaxation, with the backbone in the PNHTI-based network being much less flexible than that in the PCL-based network; this also affects the reactivity of the hydroxyl groups in the dangling chain ends. The lower activation energies in the $-\mathrm{SO}_{3} \mathrm{H}$ networks as compared to those in the $-\mathrm{COOH}$ networks are not in line with the results of a recent study that showed that stronger acids lead to higher activation energies. ${ }^{19}$ This study dealt with "classical" transesterification reactions, that is, an acid-catalyzed nucleophilic attack of an alcohol on an ester. It was shown ${ }^{24}$ by $\mathrm{Du}$ Prez and co-workers, however, that the mechanism in the $-\mathrm{COOH}$ systems (produced by linking branched polyesters with PMDA) is different and involves an anhydride intermediate. In order to investigate whether a similar mechanism is at play in the $-\mathrm{SO}_{3} \mathrm{H}$-containing networks, we studied the following model unimolecular decomposition reaction:

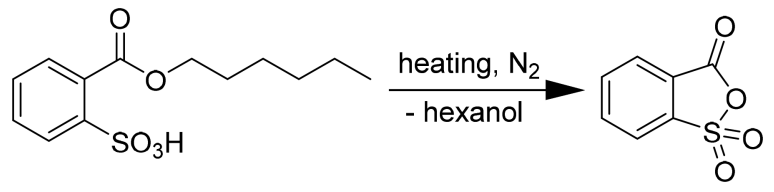

Variable temperature infrared spectra of 2-sulfo hexyl phthalate were collected from 40 to $200{ }^{\circ} \mathrm{C}$ under $\mathrm{N}_{2}$ at a heating rate of $5{ }^{\circ} \mathrm{C} / \mathrm{min}$ and are shown in Figure 3. The

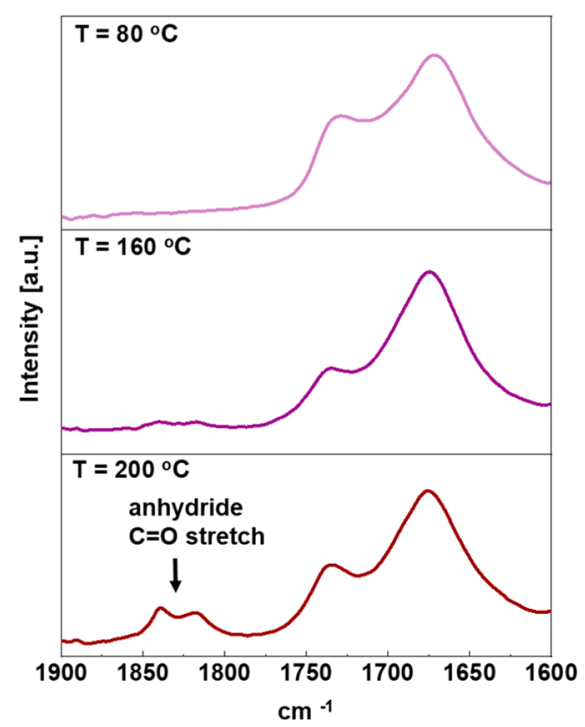

Figure 3. Variable temperature infrared spectra of 2-sulfo hexyl phthalate. .

emerging double absorption band at around $1840 \mathrm{~cm}^{-1}$, which can be assigned to the asymmetric carbonyl stretch in a carboxylate anhydride ${ }^{27}$ becomes evident at temperatures above $160{ }^{\circ} \mathrm{C}$ (the boiling point of hexanol is $157^{\circ} \mathrm{C}$ ). Since the leaving $\mathrm{OH}$-end groups in the polyester networks are nonvolatile, this reaction is reversible in the network.

The results of stress relaxation experiments on networks with different cross-link densities, prepared using different $\mathrm{OH}$ to linker ratios $\left(r=n_{\mathrm{OH}} / n_{\text {linker }}\right)$ are shown in Figure $4 \mathrm{a}$. It is clear from this figure that the relaxation times do not depend on the excess of free $\mathrm{OH}$ groups, and this result is also 
(a)

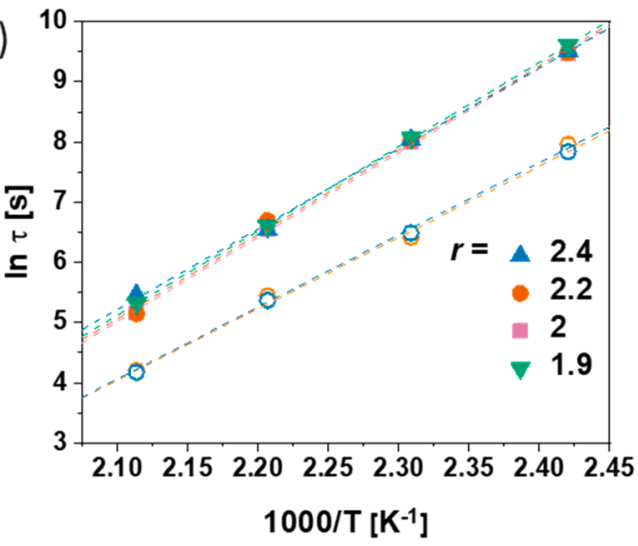

(b)

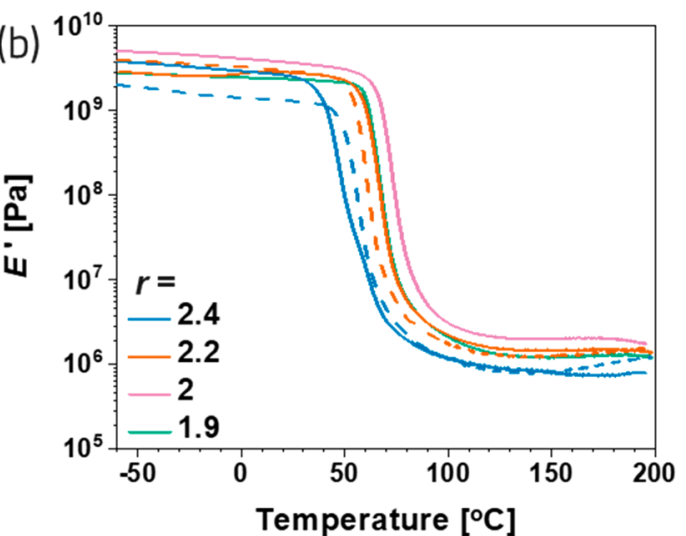

Figure 4. (a) Arrhenius plots of PNHTI-based networks with different feeding ratios $r=n_{\mathrm{OH}} / n_{\text {linker }}$ : (closed symbols) $-\mathrm{COOH}$ network, (open symbols) $-\mathrm{SO}_{3} \mathrm{H}$ network. (b) Corresponding DMA curves: (solid lines) $-\mathrm{COOH}$ networks, (dashed lines) $-\mathrm{SO}_{3} \mathrm{H}$ networks.

consistent with a dissociative mechanism in both the $-\mathrm{COOH}$ - and $-\mathrm{SO}_{3} \mathrm{H}$-containing networks. Even in the absence of an excess of $\mathrm{OH}$ groups (i.e., $r=1.9$ ), efficient stress relaxation takes place.

Although different cross-link densities do not result in different relaxation rates, they do lead to different thermomechanical properties, as is clear from the results in Figure $4 \mathrm{~b}$. This figure contains the DMA results for networks prepared using different ratios $r$ of the number of $\mathrm{OH}$ groups to the number of linkers. The first thing to note is that in all cases the rubbery plateau extends up to temperatures higher than $T_{\mathrm{g}}+$ $150{ }^{\circ} \mathrm{C}$; the PCL-based network starts to display viscous behavior at $T=T_{\mathrm{g}}+140{ }^{\circ} \mathrm{C}$ at an angular frequency of $\sim 10^{-1}$ $\mathrm{rad} / \mathrm{s}$ (see Figure S8 in the SI). Furthermore, as the ratio $r$ decreases from 2.4 (i.e., an excess of free $\mathrm{OH}$ groups) to a stoichiometric ratio of 2 , the glass transition temperatures $\left(T_{\mathrm{g}}\right)$ and the rubbery plateau moduli increase, as expected. When $r$ further decreases (resulting in an excess of linker), the $T_{\mathrm{g}}$ and rubbery plateau decrease again. Networks with the same $r$ (and theoretical cross-link density), but different acid groups, have similar rubbery plateaus and $T_{\mathrm{g}}$ values.

Finally, we investigated the "persistence" of the reversibility of the networks by subjecting them to four stress relaxation cycles at $180{ }^{\circ} \mathrm{C}$, and the results for the PNHTI-based $-\mathrm{COOH}$ - and $-\mathrm{SO}_{3} \mathrm{H}$-containing networks are shown in Figure $5 \mathrm{a}$ and $\mathrm{b}$, respectively.

From these results it is immediately clear that stress relaxation becomes slower with an increasing number of cycles
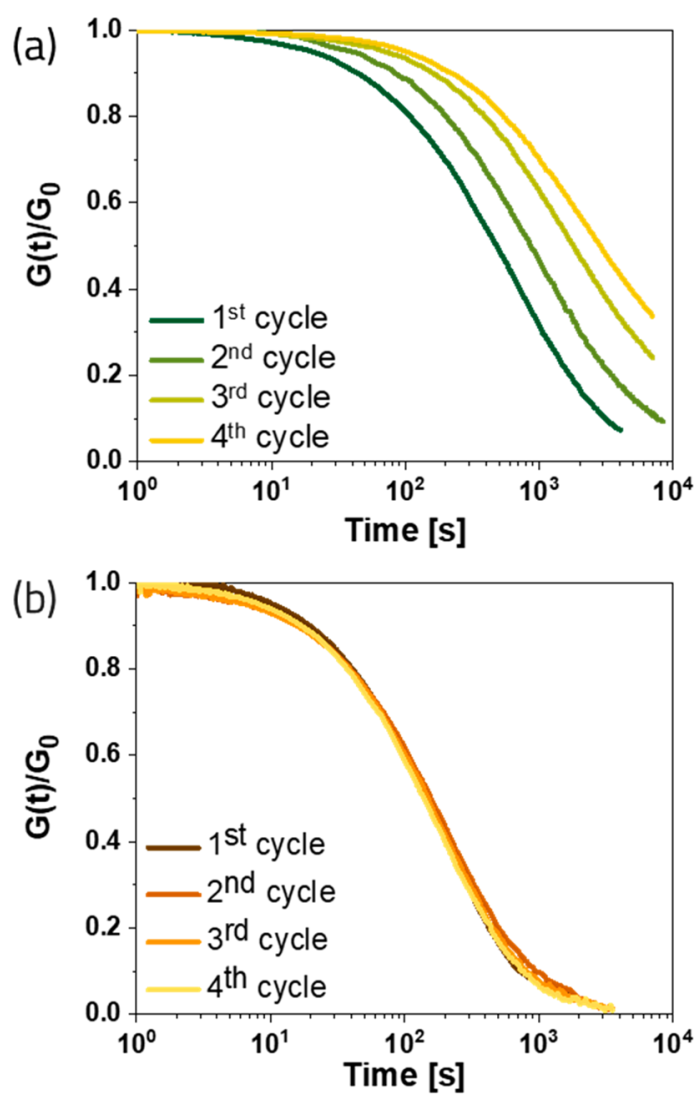

Figure 5. Multiple cycles of oscillatory rheology step-strain stress relaxation experiments at $180{ }^{\circ} \mathrm{C}$ on PNHTI-based networks with $r=$ $n_{\mathrm{OH}} / n_{\text {linker }}=2.4$ with (a) neighboring $-\mathrm{COOH}$ and (b) $-\mathrm{SO}_{3} \mathrm{H}$ groups.

in the case of the $-\mathrm{COOH}$-containing networks, but remains the same in the $-\mathrm{SO}_{3} \mathrm{H}$-containing networks. The most likely reason for this difference in behavior is the fact that the free $\mathrm{COOH}$ groups from the PMDA linker can undergo esterification reactions, effectively transforming the diesters from the reversible 1,4- and 1,3-diesters to form the irreversible 1,2-diesters, (or, to some extent, even further esterification reactions to triesters with one acid group or tetra-esters, see SI, Table S3), while in the case of the $\mathrm{SO}_{3} \mathrm{H}$ groups, such transesterifications cannot take place. Since the dynamics of the network in the absence of a transesterification catalyst depend on the ability to form anhydrides, reactions resulting in a reduction in the number of neighboring acid groups lead to a reduction in dynamic bonds and a subsequent slower relaxation rate.

In conclusion, we have demonstrated that the strategy to prepare dynamic polyester networks through intramolecular catalysis by neighboring group participation in phthalic monoesters, reported by Du Prez and co-workers, is even more effective with sulfonic acid neighboring groups. The dissociative mechanism involving intermediate anhydrides allows for full stress relaxation and is a useful principle in dynamic covalent networks, because it obviates the need for added low molecular weight catalysts with associated issues of leaching. Intramolecular catalysis by sulfonic acids leads to significantly faster stress relaxation than with intramolecular carboxylic acids. Moreover, while the carboxylic acid neighboring groups are prone to inactivation by ester formation, this reaction is suppressed in sulfonic acid 
neighboring groups because their esterification is unfavorable. As a result, the sulfonic acid containing systems maintain the same stress relaxation rates after multiple stress relaxation experiments at higher temperature, while relaxation of the phthalic monoester network is slowing down under these conditions. Intramolecular catalysis promises to be a general strategy in dynamic polymers, and its application beyond transesterification reactions will be the subject of further research.

\section{ASSOCIATED CONTENT}

\section{sI Supporting Information}

The Supporting Information is available free of charge at https://pubs.acs.org/doi/10.1021/acsmacrolett.9b01023.

Full experimental details and additional results (PDF)

\section{AUTHOR INFORMATION}

\section{Corresponding Authors}

Rint P. Sijbesma - Department of Chemical Engineering \& Chemistry and Institute for Complex Molecular Systems, Eindhoven University of Technology, 5600 MB Eindhoven, The

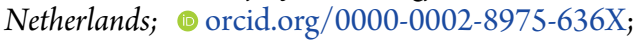

Email: r.p.sijbesma@tue.nl

Johan P. A. Heuts - Department of Chemical Engineering \& Chemistry and Institute for Complex Molecular Systems,

Eindhoven University of Technology, 5600 MB Eindhoven, The

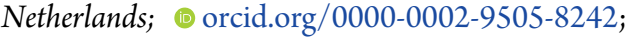

Email: j.p.a.heuts@tue.nl

\section{Authors}

Huiyi Zhang - Department of Chemical Engineering \& Chemistry and Institute for Complex Molecular Systems, Eindhoven University of Technology, 5600 MB Eindhoven, The Netherlands

Soumabrata Majumdar - Department of Chemical Engineering \& Chemistry and Institute for Complex Molecular Systems, Eindhoven University of Technology, 5600 MB Eindhoven, The Netherlands

Rolf A. T. M. van Benthem - Department of Chemical Engineering \& Chemistry and Institute for Complex Molecular Systems, Eindhoven University of Technology, $5600 \mathrm{MB}$ Eindhoven, The Netherlands; DSM Materials Science Center, 6167 RD Geleen, The Netherlands

Complete contact information is available at:

https://pubs.acs.org/10.1021/acsmacrolett.9b01023

\section{Funding}

This work was funded by the Dutch Research Council (NWO), Project No. 731.016.202.

\section{Notes}

The authors declare no competing financial interest.

\section{ACKNOWLEDGMENTS}

We gratefully acknowledge synthetic contributions to 2,5bis(methoxy-carbonyl) benzenesulfonic acid by Mika Koenen.

\section{REFERENCES}

(1) Wojtecki, R. J.; Meador, M. A.; Rowan, S. J. Using the dynamic bond to access macroscopically responsive structurally dynamic polymers. Nat. Mater. 2011, 10 (1), 14-27.
(2) Winne, J. M.; Leibler, L.; Du Prez, F. E. Dynamic covalent chemistry in polymer networks: a mechanistic perspective. Polym. Chem. 2019, 10 (45), 6091-6108.

(3) Denissen, W.; Winne, J. M.; Du Prez, F. E. Vitrimers: permanent organic networks with glass-like fluidity. Chemical Science 2016, 7 (1), $30-38$.

(4) Kloxin, C. J.; Bowman, C. N. Covalent adaptable networks: smart, reconfigurable and responsive network systems. Chem. Soc. Rev. 2013, 42 (17), 7161-7173.

(5) Chakma, P.; Konkolewicz, D. Dynamic Covalent Bonds in Polymeric Materials. Angew. Chem., Int. Ed. 2019, 58 (29), 96829695.

(6) Chen, Y.; Diaz-Dussan, D.; Wu, D.; Wang, W.; Peng, Y.-Y.; Asha, A. B.; Hall, D. G.; Ishihara, K.; Narain, R. Bioinspired self-healing hydrogel based on benzoxaborole-catechol dynamic covalent chemistry for 3D cell encapsulation. ACS Macro Lett. 2018, 7 (8), 904-908.

(7) Dahlke, J.; Zechel, S.; Hager, M. D.; Schubert, U. S. How to Design a Self-Healing Polymer: General Concepts of Dynamic Covalent Bonds and Their Application for Intrinsic Healable Materials. Adv. Mater. Interfaces 2018, 5 (17), 1800051.

(8) Sowan, N.; Cox, L. M.; Shah, P. K.; Song, H. B.; Stansbury, J. W.; Bowman, C. N. Dynamic covalent chemistry at interfaces: development of tougher, healable composites through stress relaxation at the resin-silica nanoparticles interface. Adv. Mater. Interfaces 2018 , 5 (18), 1800511.

(9) Zou, W.; Dong, J.; Luo, Y.; Zhao, Q.; Xie, T. Dynamic Covalent Polymer Networks: from Old Chemistry to Modern Day Innovations. Adv. Mater. 2017, 29 (14), 1606100.

(10) Shi, Q.; Yu, K.; Kuang, X.; Mu, X.; Dunn, C. K.; Dunn, M. L.; Wang, T.; Qi, H. J. Recyclable 3D printing of vitrimer epoxy. Mater. Horiz. 2017, 4 (4), 598-607.

(11) Zhang, B.; Kowsari, K.; Serjouei, A.; Dunn, M. L.; Ge, Q. Reprocessable thermosets for sustainable three-dimensional printing. Nat. Commun. 2018, 9 (1), 1831.

(12) Zheng, N.; Hou, J.; Zhao, H.; Wu, J.; Luo, Y.; Bai, H.; Rogers, J. A.; Zhao, Q.; Xie, T. Mechano-Plastic Pyrolysis of Dynamic Covalent Polymer Network toward Hierarchical 3D Ceramics. Adv. Mater. 2019, 31 (11), 1807326.

(13) Yang, Y.; Pei, Z.; Li, Z.; Wei, Y.; Ji, Y. Making and remaking dynamic $3 \mathrm{D}$ structures by shining light on flat liquid crystalline vitrimer films without a mold. J. Am. Chem. Soc. 2016, 138 (7), 21182121.

(14) Denissen, W.; De Baere, I.; Van Paepegem, W.; Leibler, L.; Winne, J.; Du Prez, F. E. Vinylogous Urea Vitrimers and Their Application in Fiber Reinforced Composites. Macromolecules 2018, 51 (5), 2054-2064.

(15) Capelot, M.; Montarnal, D.; Tournilhac, F.; Leibler, L. MetalCatalyzed Transesterification for Healing and Assembling of Thermosets. J. Am. Chem. Soc. 2012, 134 (18), 7664-7667.

(16) Zhou, Y.; Goossens, J. G. P.; Sijbesma, R. P.; Heuts, J. P. A. Poly(butylene terephthalate)/Glycerol-based Vitrimers via Solid-State Polymerization. Macromolecules 2017, 50 (17), 6742-6751.

(17) Altuna, F. I.; Pettarin, V.; Williams, R. J. Self-healable polymer networks based on the cross-linking of epoxidised soybean oil by an aqueous citric acid solution. Green Chem. 2013, 15 (12), 3360-3366.

(18) Yu, K.; Taynton, P.; Zhang, W.; Dunn, M. L.; Qi, H. J. Reprocessing and recycling of thermosetting polymers based on bond exchange reactions. RSC Adv. 2014, 4 (20), 10108-10117.

(19) Self, J. L.; Dolinski, N. D.; Zayas, M. S.; Read de Alaniz, J.; Bates, C. M. Brønsted-Acid-Catalyzed Exchange in Polyester Dynamic Covalent Networks. ACS Macro Lett. 2018, 7, 817-821.

(20) Capelot, M.; Unterlass, M. M.; Tournilhac, F.; Leibler, L. Catalytic Control of the Vitrimer Glass Transition. ACS Macro Lett. 2012, 1 (7), 789-792.

(21) Nakatake, D.; Yokote, Y.; Matsushima, Y.; Yazaki, R.; Ohshima, T. A highly stable but highly reactive zinc catalyst for transesterification supported by a bis (imidazole) ligand. Green Chem. 2016, 18 (6), 1524-1530. 
(22) Liu, T.; Zhang, S.; Hao, C.; Verdi, C.; Liu, W.; Liu, H.; Zhang, J. Glycerol Induced Catalyst-Free Curing of Epoxy and Vitrimer Preparation. Macromol. Rapid Commun. 2019, 40 (7), 1800889.

(23) Han, J.; Liu, T.; Zhang, S.; Hao, C.; Xin, J.; Guo, B.; Zhang, J. Hyperbranched Polymer Assisted Curing and Repairing of an Epoxy Coating. Ind. Eng. Chem. Res. 2019, 58 (16), 6466-6475.

(24) Delahaye, M.; Winne, J. M.; Du Prez, F. E. Internal catalysis in covalent adaptable networks: phthalate monoester transesterification as a versatile dynamic crosslinking chemistry. J. Am. Chem. Soc. 2019, 141 (38), 15277-15287.

(25) Ogden, W. A.; Guan, Z. Recyclable, strong and highly malleable thermosets based on boroxine networks. J. Am. Chem. Soc. 2018, 140 (20), 6217-6220.

(26) Röttger, M.; Domenech, T.; van der Weegen, R.; Breuillac, A.; Nicoläy, R.; Leibler, L. High-performance vitrimers from commodity thermoplastics through dioxaborolane metathesis. Science 2017, 356 (6333), 62-65.

(27) Silverstein, R. M.; Bassler, G. C. Spectrometric identification of organic compounds. J. Chem. Educ. 1962, 39 (11), 546. 